\title{
Smoking in the workplace: do smoking patterns and attitudes reflect the legislative environment?
}

\author{
Linda L Pederson, Shelley B Bull, Mary Jane Ashley
}

\begin{abstract}
Objective - With regard to the workplace, to examine restrictions on smoking, smoking at work, attitudes toward and reactions to restrictions, and workplace programmes in the context of the legislative environment.

Design - Population-based telephone interview survey of adult residents of the jurisdictions of Metropolitan Toronto, Ontario, Canada.

Subjects-Workers within the City of Toronto $(n=374)$ were compared with other workers $(n=536)$, because their legislative environments with regard to workplace smoking were markedly different, with workplaces in the City of Toronto being covered by a much more stringent bylaw.
\end{abstract}

Results-In comparison with other workers, City of Toronto workers reported workplace restrictions to be more common and widespread. These workers were also less likely to smoke at work, and more likely to smoke less at work and to have cut down on smoking at work. Quitsmoking rates, however, were similar. There was evidence of some compensatory smoking outside work, but additional compensation in association with more stringent restrictions was not found. City workers and other workers were similar in their support for smokefree workplaces, in their attitudes to the role of governments in regulating workplace smoking, and in their perceptions of conflict between smokers and nonsmokers. Reports of quit-smoking programmes and educational interventions in the workplace were similarly uncommon, although both groups of workers indicated strong support for the role of business and industry in helping people quit.

Conclusions-Restrictions on smoking and smoking patterns reflected the legislative environment; a more stringent environment was associated with more restrictions and less smoking at work.

(Tobacco Control 1996; 5: 39-45)

Keywords: smoking; legislation; workplace; population survey

\section{Introduction}

In response to growing concerns about the health effects of environmental tobacco smoke (ETS) ${ }^{1-4}$ many individual workplaces have voluntarily implemented restrictions on smok- $-\frac{\bar{\sigma}}{\widehat{\phi}}$ ing, ranging from limits on where smoking can take place to total bans. ${ }^{5-7}$ In addition, some ${ }^{\text {s }}$ municipalities have passed legislation to re- $\stackrel{.}{.}$ strict or eliminate smoking in the work- $\vec{\omega}$ place. $^{8-10}$ Several studies designed to evaluate $\stackrel{ }{\omega}$ such restrictive interventions indicate reduc- $\stackrel{\vec{?}}{\mathrm{r}}$ tions in the amount smoked at work, ${ }^{11-15}$ and in smoking rates. ${ }^{11,12,16-18}$ In addition, there is $\dot{\omega}_{0}$ some evidence that approval by workers of smoking restrictions increases after their implementation. ${ }^{5}$

The City of Toronto, Ontario, Canada, (population 635395; 1991 census) is one of six 9 jurisdictions that make up Metropolitan $\vec{\bullet}$

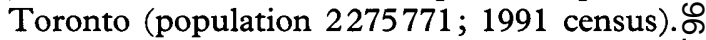
It was the first to pass a bylaw to restricti smoking in the workplace (table 1). The bylaw came into effect on 1 March 1988, and required all employers to adopt and implement a® smoking policy for each workplace and to $\frac{\mathbb{Q}}{2}$ prohibit smoking when employees could not $\vec{F}$ agree on other restrictions. It also required the 3 posting of signs restricting or prohibiting smoking. ${ }^{19}$

In a short-term evaluation of the impact of the bylaw (nine months after implementation), , we found that City workers reported significantly more changes with regard to smoking patterns in the workplace and workplace? smoking programme and policy interventionsō than did other workers in Metropolitano Toronto, ${ }^{20}$ despite the fact that one of the jurisdictions (Etobicoke, population 309993 ;응 1991 census) had implemented a similar bylaw in the interim. ${ }^{21}$ Post-implementation, there 9

Legislative environment: smoking in the workplace

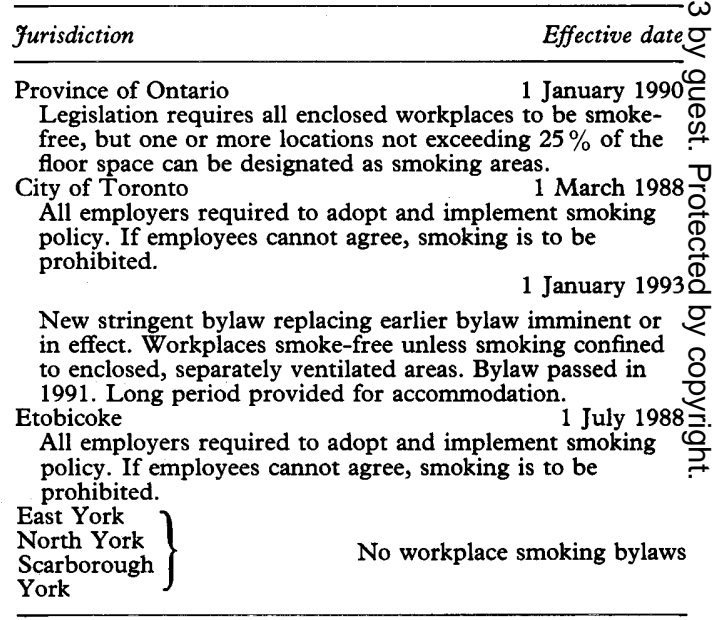

\section{Community Health
and Preventive
Medicine, Morehouse
School of Medicine,
and Drew-Meharry-
Morehouse
Consortium Cancer
Center, Atlanta,
Georgia, USA
LL Pederson
Samuel Lunenfeld
Research Institute,
Mount Sinai Hospital,
Preventive Medicine
and Biostatistics,
University of Toronto,
Ontario Tobacco \\ Community Health
and Preventive
Medicine, Morehouse
School of Medicine,
and Drew-Meharry-
Morehouse
Consortium Cancer
Center, Atlanta,
Georgia, USA
LL Pederson
Samuel Lunenfeld
Research Institute,
Mount Sinai Hospital,
Preventive Medicine
and Biostatistics,
University of Toronto,
Ontario Tobacco \\ Community Health
and Preventive
Medicine, Morehouse
School of Medicine,
and Drew-Meharry-
Morehouse
Consortium Cancer
Center, Atlanta,
Georgia, USA
LL Pederson
Samuel Lunenfeld
Research Institute,
Mount Sinai Hospital,
Preventive Medicine
and Biostatistics,
University of Toronto,
Ontario Tobacco \\ Community Health
and Preventive
Medicine, Morehouse
School of Medicine,
and Drew-Meharry-
Morehouse
Consortium Cancer
Center, Atlanta,
Georgia, USA
LL Pederson
Samuel Lunenfeld
Research Institute,
Mount Sinai Hospital,
Preventive Medicine
and Biostatistics,
University of Toronto,
Ontario Tobacco \\ Community Health
and Preventive
Medicine, Morehouse
School of Medicine,
and Drew-Meharry-
Morehouse
Consortium Cancer
Center, Atlanta,
Georgia, USA
LL Pederson
Samuel Lunenfeld
Research Institute,
Mount Sinai Hospital,
Preventive Medicine
and Biostatistics,
University of Toronto,
Ontario Tobacco Research Unit, SB Bull \\ MJ Ashley \\ Correspondence to: $\mathrm{Dr} \mathrm{L}$ Pederson, Community Medicine, Morehouse School of Medicine, Atlanta, Georgia 30310, USA}


were still reports of non-compliance with the regulations from over a third of the City workers. Additionally, although smokers reported modifying the amount they smoked overall, and how much they smoked in the workplace, there was no reduction in the prevalence of smoking from pre-implementation levels. ${ }^{20}$

Although, as expected, the bylaw had significant effects in the short-term, the differential impact over the longer term was much less certain, given the rapidly changing social norms with regard to the control of smoking in the community at large, and the continuing implementation of new restrictions on smoking, both voluntary and legislated (see table 1). For example, on 1 January 1990, legislation regulating smoking in the workplace, which had been passed by the Province of Ontario, came into force, affecting all six jurisdictions. Under this legislation all enclosed workplaces (with some exceptions) were to be smoke-free. However, an employer could designate one or more locations in an enclosed workplace as smoking areas, provided these areas did not exceed $25 \%$ of the floor area of the enclosed workplace. Designated smoking areas had to be identified by the posting of signs, but they did not have to be enclosed and separately ventilated. ${ }^{22}$

In 1991, the City of Toronto passed a new, more stringent bylaw that came into effect on 1 January 1993. This bylaw required all workplaces (with one or more employees) to be smoke-free, unless an enclosed, designated smoking area with separate ventilation was provided. Employers were required to inform their employees of the smoking restrictions, and post no-smoking and health warning signs conspicuously in smoke-free and designated smoking areas, respectively. ${ }^{23,24}$ These requirements took precedence over those of the provincial legislation. Because of the stringency of the bylaw, including the requirement for enclosed, separately ventilated smoking areas if smoking was not prohibited, a long accommodation period was provided before the bylaw came into effect.

Between December 1992 and March 1993, workers in the City of Toronto and elsewhere in the greater Toronto area were resurveyed. About half the interviews were carried out less than a month before the bylaw affecting City of Toronto workers took effect and the rest were done two months after the effective date. The purpose of this analysis is to describe restrictions on smoking, smoking at work, attitudes toward and reactions to restrictions, and workplace programmes in the context of the legislative environment that prevailed in this large Metropolitan area. Because the regulatory environment in the City of Toronto was markedly different from that in the other jurisdictions, both in the length of time that bylaw restrictions had been in place and in the stringency of restrictions that were imminent or in place at the time of the survey, we compared workers in this jurisdiction with workers in the others.

\section{Methods}

SAMPLING DESIGN

Because the survey had broader objectives than the ones addressed in this paper, the target population included all residents of Metropolitan Toronto 18 years old or older (population 1819415; 1991 census). The sampled population consisted of all residents living in households with active telephone numbers during the data collection phase (97\% of the population). To obtain a representative probability sample from the target population, a two-stage design was employed. First stage units were households within Metropolitan Toronto. Households with active telephones were selected, using random digit dialling. The second stage of sampling involved selection of an individual respondent from the household, by choosing the person whose month and day of birth was most recent. $^{25}$

\section{DATA COLLECTION}

Data were collected during a standardised 25-30-minute computer-assisted telephone interview conducted in December 1992 and in March 1993, using a pretested questionnaire available in English, French, and Italian. At least eight call-backs at prespecified times during the day, in the evening, and on weekends were carried out before a number or a respondent was declared unreachable. For respondents who worked outside the home, items included their perceptions about laws on smoking in the workplace, restrictions in their own workplaces, the smoking behaviour of the respondent and co-workers, the impact of restrictions on smoking at work, smoking cessation and educational programmes in the workplace, attitudes toward restrictions on smoking in the workplace, and sociodemographic characteristics. (A copy of the questionnaire is available from the first author.) To assess test-retest reliability, a sample of 193 respondents was recalled within two weeks and asked key questions about their smoking status, knowledge, and attitudes. Agreement was high $(K \geqslant 0.70)$ for factual items such as smoking status and place of work, but lower for attitude items such as agreement with restrictions ( $K$ ranging from 0.40 to 0.70 ).

\section{SAMPLE SIZE AND STATISTICAL ANALYSIS}

Of the 5702 telephone numbers randomly generated at the first stage of sampling, 3150 were from ineligible households, and $266 \mathrm{did}$ not have their eligibility determined. Ineligible numbers were those for households not in Metropolitan Toronto, non-residential numbers, and individuals who were incapable of being respondents either because of language difficulties or illness. From 2286 eligible households, 1429 respondents completed the interview, yielding a response rate of $62.5 \%$ for the overall survey.

The observations of 1429 respondents, both workers and non-workers, were weighted according to the number of adults in the 
household and the relative frequency in the 1991 census age-sex distribution for Metropolitan Toronto. Among the 1429 respondents, there were 910 who worked for pay outside the home. These are included in the analyses reported here; 374 worked in the City of Toronto (including 96 current smokers) and 536 worked elsewhere in the Metropolitan Toronto area or outside Metro (including 166 current smokers). With these sample sizes, differences of 7 percentage points between the City and the other workers were detectable for non-smokers and smokers combined, and differences of 14 percentage points were detectable for smokers.

Responses to the items of interest were tabulated as percentages within the two workplace groups and for all workers, and corresponding $95 \%$ confidence intervals were calculated. ${ }^{26,27}$ An overall $\chi^{2}$ test was used to assess homogeneity of responses between the groups. For responses with more than two categories, the categories in which the groups differed were determined by examining $95 \%$ confidence intervals for differences in percentages.

\section{SAMPLE REPRESENTATIVENESS}

Sociodemographic characteristics of the survey respondents, including place of residence, marital status, level of education, labour force participation, and occupation, were compared with 1991 census data for Metropolitan Toronto to examine potential bias in the sample due to non-response. The distribution of the 1429 survey respondents by place of residence was very similar to the 1991 census distribution, with $29 \%$ living in the City of Toronto and $71 \%$ in the other five Metro

Table 2 Knowledge of health risks of environmental tobacco smoke and of current laws restricting smoking in the workplace, and attitudes toward such restrictions

\begin{tabular}{|c|c|c|c|c|}
\hline & $\begin{array}{c}\text { City } \\
\text { workers }(\%) \\
(n=374)\end{array}$ & $\begin{array}{c}\text { Other } \\
\text { workers }(\%) \\
(n=536)\end{array}$ & $\begin{array}{c}\text { All } \\
\text { workers }(\%) \\
(n=910)\end{array}$ & $\begin{array}{l}\text { City vs } \\
\text { other } \\
\text { p value }\end{array}$ \\
\hline & \multicolumn{4}{|c|}{ Strongly agree/agree } \\
\hline $\begin{array}{l}\text { Second-hand smoke carries } \\
\text { health risks to non-smokers }\end{array}$ & 92.6 & 91.3 & 91.8 & 0.55 \\
\hline $\begin{array}{l}\text { Are there any laws restricting } \\
\text { smoking in the workplace? }\end{array}$ & 89.4 & 86.5 & 87.7 & 0.37 \\
\hline $\begin{array}{l}\text { Is there a law that covers } \\
\text { the whole province? }\end{array}$ & 29.1 & 31.2 & 30.3 & 0.57 \\
\hline $\begin{array}{l}\text { Does }(\star) \text { have its own law to } \\
\text { restrict smoking in the } \\
\text { workplace? }\end{array}$ & 74.1 & 61.7 & 66.8 & 0.001 \\
\hline $\begin{array}{l}\text { All workplaces covered by the } \\
\text { Yes }\end{array}$ & WS? 54.9 & 49.2 & 51.6 & 0.18 \\
\hline & $\begin{array}{l}24.3 \\
20.9\end{array}$ & $\begin{array}{l}29.3 \\
21.5\end{array}$ & $\begin{array}{l}27.2 \\
21.2\end{array}$ & 0.10 \\
\hline \multicolumn{5}{|c|}{ What do the laws say about where smoking is allowed at work? } \\
\hline Not allowed at all & 22.9 & 20.7 & 21.6 & 0.27 \\
\hline Only in certain areas & 62.8 & 60.0 & 61.1 & \\
\hline Allowed everywhere & 0.7 & 0.9 & 0.8 & \\
\hline \multicolumn{5}{|l|}{ Don't know/refused } \\
\hline $\begin{array}{l}\text { All workplaces should be } \\
\text { smoke-free }\end{array}$ & 62.5 & $\begin{array}{l}\text { Strongly } \\
61.4\end{array}$ & $\begin{array}{c}\text { agree/agree } \\
61.7\end{array}$ & 0.49 \\
\hline $\begin{array}{l}\text { Smoking should be } \\
\text { permitted at work, but only } \\
\text { in certain areas }\end{array}$ & 80.0 & 80.4 & 80.3 & 0.99 \\
\hline $\begin{array}{l}\text { Governments should make } \\
\text { laws about smoking at } \\
\text { work. }\end{array}$ & 83.1 & 78.4 & 80.3 & 0.13 \\
\hline $\begin{array}{l}\text { Each workplace should have } \\
\text { the right to decide whether } \\
\text { to permit smoking or not }\end{array}$ & 55.3 & 60.4 & 58.3 & 0.27 \\
\hline
\end{tabular}

^ Jurisdiction in which the respondent works. jurisdictions. In comparison with the census, the survey respondents over-represented married or separated individuals and high-school and university graduates. The latter findinghas also been reported by other survey researchers. ${ }^{28}$ Small differences were observed for employment status and for occupational categories (4-7 percentage points) but, because the census and survey questions for labou $\vec{\xi}$ force participation were not entirely $\mathrm{com}=\overrightarrow{\mathrm{s}}$ parable, no post-stratification adjustmentewere made and no comparisons with census: data were made for the subgroup of workerso with regard to other sociodemographic in formation.

\section{Results}

KNOWLEDGE OF HEALTH EFFECTS OF ETS, LAWS RESTRICTING SMOKING IN THE WORKPLACE AND ATTITUDES TO SUCH RESTRICTIONS $\vec{\bullet}$ Most workers in both City of Toronto work places (City workers) and workplaces outside the City were aware that ETS poses a healthrisk to non-smokers (table 2). Similarly, almos all workers knew that there were laws restrict ing smoking in the workplace, although less than a third of both groups were specificallye aware of the provincial legislation. Wher workers were asked whether or not there was of municipal workplace smoking bylaw in the jurisdiction where they worked, a majority ot both groups replied in the affirmative, althouglo in fact, as described earlier, only the Cities of Toronto and Etobicoke were so covered. $\mathrm{I} \overrightarrow{\vec{B}}$ this regard, however, significantly more City workers responded in the affirmative $(74.1 \%$ vs $61.7 \%$ ), probably reflecting the recent passage of a very stringent bylaw by the City of Toronto. Only half the workers were aware that all workplaces are covered by existing legislation (the provincial law). There were ne differences between the groups in their per ceptions of what the laws say about smoking a? work. The groups were also alike in theig attitudes toward workplace smoking restric tions; a clear majority of both groups though that governments should enact restrictions.

\section{RESTRICTIONS IN THE WORKPLACE AND} WORKERS' ATTITUDES TO THESE RESTRICTIONS There were significant differences $(p<0.001)$ between City workers and other workers in their reports of actual restrictions in their owrit workplace (table 3 ). City workers were more likely to report that smoking is not allowed ae all $(55.1 \%$ vs $35.1 \%$ ) and that smoking was? prohibited in specific areas of the workplace The large majority of both groups were satisfied or very satisfied with policies aboug smoking at work; there was a tendency fo $\vec{B}$ more City workers to be very satisfied, but overall, the differences between the groups were not statistically significant.

SMOKING IN THE WORKPLACE AND WORKERS' REACTIONS TO IT

City workers and other workers were significantly different with regard to smoking at work (table 4). In particular, city workers were 
Table 3 Restrictions on smoking in the respondent's workplace and attitudes toward these restrictions

\begin{tabular}{lcccc}
\hline & $\begin{array}{c}\text { City } \\
\text { workers }(\%) \\
(n=374)\end{array}$ & $\begin{array}{c}\text { Other } \\
\text { workers }(\%) \\
(n=536)\end{array}$ & $\begin{array}{c}\text { All } \\
\text { workers }(\%) \\
(n=910)\end{array}$ & $\begin{array}{c}\text { City vs } \\
\text { other } \\
\text { p value }\end{array}$ \\
\hline $\begin{array}{l}\text { Does the place where you work } \\
\text { have restrictions on smoking (Yes) }\end{array}$ & 87.7 & 78.3 & 82.2 & 0.01 \\
What are the restrictions? & & & & \\
None & 10.5 & 18.6 & 15.3 & 0.001 \\
Certain areas & 32.6 & 43.2 & 38.8 & \\
Not allowed at all & 55.1 & 35.1 & 43.3 & \\
Don't know/refused & 0.7 & 2.2 & 1.6 & \\
Where is smoking not allowed? & & & & \\
Special smoking room & 63.5 & 48.5 & 54.7 & 0.001 \\
Private offices & 81.3 & 67.0 & 72.8 & 0.001 \\
Rest rooms & 83.2 & 69.2 & 74.9 & 0.001 \\
Lobbies & 83.1 & 69.1 & 74.8 & 0.001 \\
All of cafeteria & 83.1 & 69.3 & 75.0 & 0.001 \\
Special section of cafeteria & 73.9 & 53.3 & 61.8 & 0.001 \\
Outside building & 56.2 & 36.1 & 44.4 & 0.001 \\
How satisfied are you with the policies about smoking at work? & & \\
Very satisfied & 57.8 & 50.1 & 53.3 & 0.10 \\
Somewhat satisfied & 26.5 & 30.0 & 28.6 & \\
Somewhat dissatisfied & 7.8 & 11.3 & 9.8 & \\
Very dissatisfied & 5.3 & 6.9 & 6.2 & \\
Don't know/refused & 2.7 & 1.8 & 2.1 & \\
\hline
\end{tabular}

Table 4 Smoking in the workplace and reactions to it

\begin{tabular}{|c|c|c|c|c|}
\hline & $\begin{array}{c}\text { City } \\
\text { workers }(\%) \\
(n=374)\end{array}$ & $\begin{array}{c}\text { Other } \\
\text { workers }(\%) \\
(n=536)\end{array}$ & $\begin{array}{c}\text { All } \\
\text { workers }(\%) \\
(n=910)\end{array}$ & $\begin{array}{l}\text { City vs } \\
\text { other } \\
\text { p value }\end{array}$ \\
\hline \multicolumn{5}{|l|}{ Smoking status (at work) } \\
\hline Never smoked & 54.1 & 50.5 & 52.0 & \multirow{5}{*}{0.01} \\
\hline Quit $\geqslant 6$ months & 16.9 & 14.2 & 15.3 & \\
\hline Quit $<6$ months & 3.5 & 4.5 & 4.1 & \\
\hline Smoker: not at work & 11.8 & 8.7 & 9.9 & \\
\hline Smoker: at work & 13.8 & 22.2 & 18.8 & \\
\hline \multicolumn{5}{|c|}{ In your workplace would you say... } \\
\hline Most workers smoke & 6.9 & 10.3 & 8.9 & \multirow[t]{6}{*}{0.12} \\
\hline About half smoke & 13.3 & 17.9 & 16.0 & \\
\hline Less than half & 39.4 & 37.9 & 38.5 & \\
\hline Almost none smoke & 27.3 & 23.8 & 25.2 & \\
\hline None smoke & 10.4 & 7.8 & 8.9 & \\
\hline Don't know/refused & 2.7 & 2.3 & 2.4 & \\
\hline \multicolumn{5}{|c|}{ Are you bothered by other people smoking at work? } \\
\hline Always & 11.4 & 9.8 & 10.4 & \multirow{6}{*}{0.42} \\
\hline Most times & 4.7 & 5.1 & 4.9 & \\
\hline Sometimes & 10.9 & 13.7 & 12.6 & \\
\hline No smokers at work & 13.1 & 10.0 & 11.3 & \\
\hline No & 59.4 & 60.7 & 60.2 & \\
\hline Don't know/refused & 0.4 & 0.8 & 0.6 & \\
\hline \multicolumn{5}{|c|}{ If another employee smokes in your work area, do you...(Yes) } \\
\hline Ask him/her to stop? & 54.8 & 50.0 & 52.0 & 0.15 \\
\hline $\begin{array}{l}\text { Feel like asking } \\
\text { him/her to stop, but } \\
\text { don't feel comfortable } \\
\text { doing it? }\end{array}$ & 32.8 & 29.3 & 30.7 & 0.26 \\
\hline $\begin{array}{l}\text { doing it } \\
\text { Indicate disapproval } \\
\text { without saying so? }\end{array}$ & 26.0 & 25.3 & 25.3 & 0.82 \\
\hline Ask him/her to leave? & 26.8 & 24.3 & 25.3 & 0.40 \\
\hline Try to move away? & 39.7 & 44.1 & 42.3 & 0.19 \\
\hline $\begin{array}{l}\text { Continue working } \\
\text { without noticing? }\end{array}$ & 26.3 & 33.4 & 30.5 & 0.02 \\
\hline
\end{tabular}

much less likely to smoke at work. There were no statistically significant differences between the groups in their perceptions of smoking by co-workers, although there was a tendency for City workers to report less smoking than was the case for other workers. For the most part, the groups were similar in their reports of being bothered by others' smoking and also in their responses to how they would respond if another employee smoked in their work area. However, fewer City workers than other workers responded that they would continue working without noticing that smoking was occurring.

SMOKERS' OWN SMOKING IN THE WORKPLACE City workers who smoked were much less likely to report that they smoked at work than were other workers who smoked (table 5) and were much less likely to smoke 11 or more cigarettes per day. There were also some differences between the groups in where they smoked; fewer City workers smoked in the lunchroom/cafeteria, in designated smoking areas, and outside the building.

CHANGES IN SMOKING IN THE WORKPLACE SINCE LAWS CAME INTO EFFECT

More City of Toronto workers than other workers reported that notices about nonsmoking areas (a specific requirement of the City of Toronto bylaw) were posted (table 6 ). The groups, however, were similar in their perceptions of how most smokers were reacting to the restrictions, and of changes that took place in smoking at work. They were also similar in their perceptions of conflict arising from the restrictions. With regard to changes in smokers' own smoking as a result of the restrictions, City workers were more likely to report that they had cut down, and less likely to report that smoking at work had stayed the same.

\section{SMOKING PROGRAMMES IN THE WORKPLACE}

There were no differences between the groups in the prevalence of smoking cessation programmes, incentive programmes, or the provision of educational messages or programmes. The frequencies of all these activities were minimal. Overall, less than $10 \%$ of workers indicated that smoking cessation programmes were offered in their workplace and only $22 \%$ reported receiving pamphlets or being offered lectures about smoking and health. In contrast, a clear majority of workers in each group thought that business and industry should do more to help people quit, and about half thought that quit-smoking programmes should be put on during work hours. Most workers $(77 \%)$ thought such programmes should be free.

\section{Discussion}

Although all workplaces in Metropolitan Toronto were covered by the provincial Smoking in the Workplace Act, ${ }^{22}$ workplaces in the City of Toronto were, in addition, covered by much more stringent restrictions that were either in effect or imminent when the data were collected. ${ }^{23}$ We hypothesised that the situation in the City of Toronto with regard to workplace smoking would reflect this legislative environment, and that, as a consequence, differences would be found between City workers and others workers in reports of restrictions on smoking, patterns of smoking, attitudes towards restrictions, reactions to smoking, and workplace programmes.

With regard to restrictions on smoking and patterns of smoking, the findings confirm the hypothesis. City workers were much more likely to report restrictions in a range of workplace settings and much less likely to smoke at work. If they did smoke, they smoked less than their non-City counterparts. Com- 
Table 5 Smokers' reports on own smoking at work

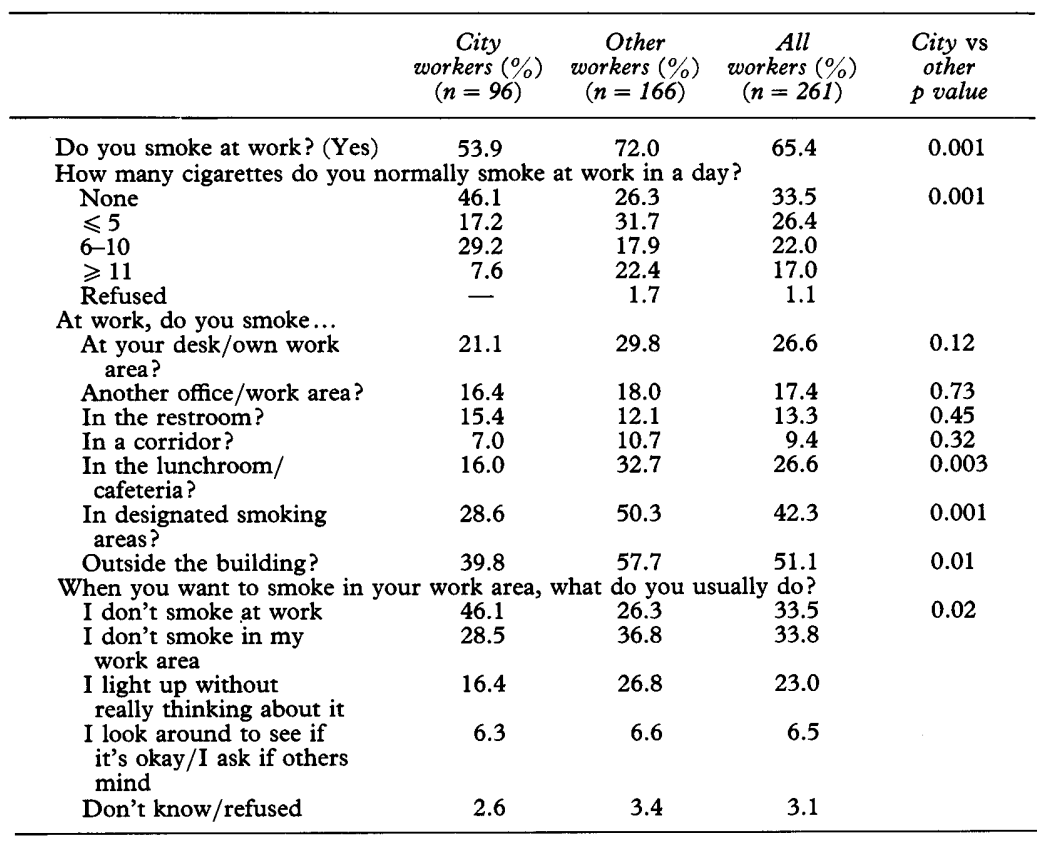

Table 6 Changes in the workplace since smoking laws came into effect

\begin{tabular}{|c|c|c|c|c|}
\hline & $\begin{array}{c}\text { City } \\
\text { workers }(\%) \\
(n=374)\end{array}$ & $\begin{array}{c}\text { Other } \\
\text { workers }(\%) \\
(n=536)\end{array}$ & $\begin{array}{c}\text { All } \\
\text { workers }(\%) \\
(n=910)\end{array}$ & $\begin{array}{c}\text { City vs } \\
\text { other } \\
p \text { value }\end{array}$ \\
\hline $\begin{array}{l}\text { Notices posted about non- } \\
\text { smoking areas (Yes) }\end{array}$ & 62.5 & 54.7 & 57.9 & 0.02 \\
\hline $\begin{array}{l}\text { Other information about non- } \\
\text { smoking areas provided (Yes) }\end{array}$ & 16.8 & 13.9 & 15.1 & 0.22 \\
\hline \multicolumn{5}{|c|}{ What has happened to people's smoking at work? (Yes) } \\
\hline $\begin{array}{l}\text { A lot of smokers have... } \\
\text { Quit }\end{array}$ & 229 & 246 & 23.9 & 0.54 \\
\hline $\begin{array}{l}\text { Quit } \\
\text { Tried to quit }\end{array}$ & 48.5 & 55.2 & 52.4 & 0.05 \\
\hline Smokers have cut down & 55.4 & 59.8 & 58.0 & 0.19 \\
\hline $\begin{array}{l}\text { People smoke less at work, } \\
\text { but more outside work }\end{array}$ & 52.3 & 55.7 & 54.3 & 0.32 \\
\hline $\begin{array}{l}\text { Non-smokers are more likely } \\
\text { to ask people not to smoke }\end{array}$ & 57.3 & 59.0 & 58.3 & 0.62 \\
\hline $\begin{array}{l}\text { People tend to smoke only in } \\
\text { certain areas }\end{array}$ & 77.1 & 75.5 & 76.2 & 0.57 \\
\hline \multicolumn{5}{|c|}{ Between smokers and non-smokers there has been ... } \\
\hline A lot of conflict & 17.2 & 19.1 & 18.3 & 0.09 \\
\hline Some conflict & 41.3 & 42.3 & 41.9 & \\
\hline Not much conflict & 30.3 & 23.6 & 26.4 & \\
\hline Don't know/refused & 11.3 & 15.0 & 13.5 & \\
\hline \multicolumn{5}{|c|}{ As a result of restrictions on smoking at work } \\
\hline $\begin{array}{l}\text { have you...(Yes) } \\
\text { Smokers only: }\end{array}$ & $(n=96)$ & $(n=166)$ & $(n=261)$ & \\
\hline Tried to quit & 26.7 & 23.2 & 24.5 & 0.52 \\
\hline Cut down & 64.4 & 47.1 & 53.5 & 0.01 \\
\hline Stopped smoking at work & 25.6 & 16.8 & 20.0 & 0.09 \\
\hline $\begin{array}{l}\text { Smoke less at work, more } \\
\text { at home }\end{array}$ & 40.7 & 40.6 & 40.6 & 0.99 \\
\hline $\begin{array}{l}\text { Smoking at work has } \\
\text { stayed the same }\end{array}$ & 32.4 & 50.4 & 43.8 & 0.01 \\
\hline
\end{tabular}

pared with other workers, more City workers who smoked also reported that, as a result of restrictions on smoking at work, they had cut down on their smoking. It is important to note that the changes did not appear to have been associated with additional conflict between smokers and non-smokers in the workplace. City workers were no more likely than other workers to report such conflict.

Although patterns of restrictions and smoking at work clearly reflected legislated restrictions, there was less evidence in this study of an effect of restrictions on smoking cessation. Former smokers were only slightly more prevalent among City workers than among other workers $(20.4 \%$ and $18.7 \%$, respect- ively), and there was no statistically significant difference in the percentages of smokers reporting that they had tried to quit $(26.7 \%$ and $23.2 \%$, respectively). Some studies havedemonstrated significant reductions in smoking rates following implementation of site-o specific workplace restrictions. ${ }^{11,12,16-18}$ For many smokers, sustained quitting appears to be a long-term process of change involving several steps. ${ }^{29}$ Some authors have suggested that a decrease in the amount smoked in response to restrictions may be an importanten step in the cessation process. ${ }^{30,31}$ This hyp- $-\bar{\nabla}$ othesis requires evaluation in longitudinalo studies.

Our findings do suggest that some workers $\overrightarrow{0}$ who decreased their smoking at work may have compensated by smoking more outside theo workplace. However, there was no evidence of additional compensation in City workers compared with other workers, even though theirw smoking at work was substantially less. Abouto $40 \%$ of both City and other workers reported that as a result of restrictions on smoking at work, they smoked less at work but more at home. This finding raises the possibility that workplace restrictions, although effective in $\overrightarrow{0}$ reducing workplace exposures, may have somes unintended adverse effects. Increased smoking in the home may increase the exposure of spouses and children to environmental tobacco smoke, clearly an undesirable outcome. ${ }^{2}$ Fewn studies have specifically examined this issue $\mathbb{D}$ but some of the available findings do suggest that some compensation may occur even though overall consumption declines. ${ }^{30}$ Fors example, Borland et al. ${ }^{32}$ found small overalto increases in cigarette consumption outside the workplace following implementation of a work-0 site ban and Scott and Gerberich ${ }^{18}$ reported that $21.2 \%$ of smokers reported smoking moreo outside of work following a ban. Brigham et al., ${ }^{14}$ however, found no compensatory effect $\overrightarrow{\overrightarrow{0}}$ The issue of compensation warrants specifico study.

Although smoking patterns in City workersô and other workers clearly reflected differences in the stringency of the legislated restrictions? which were in place, attitudes to smoking restrictions did not differ between the two groups. Similar percentages, $62.5 \%$ and $61.4 \%$, of City and other workers, respect ively, agreed with the statement that work places should be smoke-free, and $80 \%$ of both groups agreed that smoking should be permitted at work, but only in certain areas. A clear majority of both groups agreed thate governments should make laws concerning smoking. On the other hand, a majorityo indicated that each workplace should have the right to decide whether to permit smoking or $\vec{Q}$ not. Although these responses suggest somed inconsistency in attitudes toward worksiteo smoking restrictions, the overall findings in-0 dicate widespread support for workplace smoking restrictions. It is interesting to notethat the level of satisfaction in general among workers is remarkably similar to that reported by owners and managers in City of Toronto at over $80 \%$. $^{24}$ 
Two findings require some additional explanation. Because the 1991 City of Toronto bylaw requires that smoking be confined to separate enclosed areas which are separately ventilated, on the surface it may appear incongruent that significantly more City workers reported that smoking was not allowed in special smoking rooms. As well, City workers who smoked were much less likely to report that they smoked in designated smoking areas. However, when the bylaw was passed many workplaces would not have had areas suitable for smoking that were enclosed and separately ventilated, and further, because of cost considerations, their construction would be unlikely. Thus, the alternative option, that of prohibiting smoking, was much more likely to occur in City workplaces than in workplaces elsewhere in Metropolitan Toronto. These apparently incongruent findings are consistent with this scenario, as are the findings that City of Toronto workers who smoked were much less likely to smoke at work.

With regard to smoking cessation programmes and other cessation measures in the workplace, there were no differences between the reports of City and other workers. Cessation programmes in workplaces overall were uncommon. Similarly, educational messages and incentive programmes were minimal. There is now considerable evidence that workplace cessation programmes can be effective ${ }^{33-37}$ More than three-quarters of workers in Metropolitan Toronto agreed that business and industry should do more to help people quit and that quit smoking programmes should be free; $55 \%$ indicated that quit smoking programmes should be put on during work hours. These findings suggest that workplace smoking cessation should be a priority on the programme agenda.

These findings should be interpreted with caution. It is not clear how much misrepresentation of smoking behaviour by smokers may have occurred because of the growing social unacceptability of smoking. Recent studies suggest that, although some misrepresentation may occur, its frequency is low. ${ }^{38,39}$ If such a bias were operating to any extent, it would tend to exaggerate differences between City and other workers. It should also be kept in mind that the survey was conducted just before and two months after implementation of the most recent City of Toronto bylaw and this analysis combines information from both periods. Because of the stringency of the bylaw, which required either that smoking be prohibited or that it be restricted to enclosed, separately ventilated smoking areas, a long period of accommodation was provided between the passage of the legislation and the implementation date. Many workplaces would have accommodated to the requirements of the bylaw by the time the first data were collected. However, some would not have done so, and thus, in all likelihood, differences between City workers and other workers would have been even more marked if all of the interviews had been carried out after 1 January 1993.

This report presents results from a single cross-sectional survey. Therefore, it is not possible to attribute differences to the legislation. It might be that differences existed long before such restrictive measures were enacted and, in fact, led directly to their acceptability and enactment. The purpose of this report was to describe the current situation, not to explain what lead to that situation. Future reports will attempt to trace both the changes in restrictive measures and changes in knowledge, attitudes, and behaviour.

Despite the changes that had occurred, workplaces were not smoke-free. The provincial legislation, the only legislation pertaining to most workplaces in Ontario, is clearly deficient in that unlike the City of Toronto bylaw, it does not require that designated smoking areas be enclosed and separately ventilated. Continuing efforts are required to ensure that legislators, as well as workers, and owners and managers, are fully aware of the adverse effects of ETS on health, and that effective restrictions on smoking in the workplace, mandated by rigorous legislation, are put in place and enforced.

Notwithstanding its health protective effect, the control of smoking in the workplace may be the most significant step that now can be taken to further enhance the growing social unacceptability of smoking. ${ }^{5}$ Because of the large numbers in the workforce, the potential for impact is great. As well, in the worksite, particularly, the benefits of restrictions may translate into economic factors, such as increased productivity and reductions in days lost from work, cleaning costs, costs from ventilation, and fire insurance costs. In addition, the workplace should be an ideal setting for cessation programmes, and offers special opportunities for enhancement of programme uptake and effectiveness through mechanisms such as incentives and benefits policies that provide financial support. ${ }^{34,35,40}$

This research was funded by a grant from Health and Welfare Canada. Dr Pederson was a member of the Department of Epidemiology and Biostatistics, University of Western Ontario. Dr Bull is a National Health Research Scholar under the National Health Research and Development Program. The authors would like to thank Janice Smith for the data analysis and Lisa Wilson for help with the manuscript.

1 US Department of Health, Education, and Welfare. Smoking and health. A report of the Surgeon General, 1979. Rockville, Maryland: Public Health Service, Office on Smoking and Health, 1979 (DHEW Publication No (PHS) 79-50066.)

2 US Environmental Protection Agency. Respiratory health effects of passive smoking: lung cancer and other disorders. Washington, DC: US Environmental Protection Agency, 1992. (Publication EPA/600/6-90/006F.)

3 Robbins AS, Abbey DE, Lebowitz MD. Passive smoking and chronic respiratory disease symptoms in nonsmoking adults. Int $\mathcal{f}$ Epidemiol 1993; 22:809-17.

4 Wells AJ. Passive smoking as a cause of heart disease. $f \mathrm{Am}$ Coll Cardiol $1994 ; 24$ : 546-54.

5 Fielding JE. Smoking control at the workplace. Annu Rev Public Health 1991; 12: 209-34.

6 Glasgow RE, Sorensen G, Corbett K. Worksite smoking control activities: Prevalence and related worksite characteristics from the COMMIT study, 1990. Prev Med $1992 ; 21: 688-700$.

7 Kinne S, Kristal AR, White E, Hunt J. Work-site smoking policies: Their population impact in Washington State. Am f Public Health 1993; 83: 1031-33.

8 Rigotti NA, Pashos CL. No-smoking laws in the United States. An analysis of state and city actions to limit smoking in public places and workplaces. $\mathscr{F} A M A 1991$ 266: $3162-7$.

9 Health and Welfare Canada. Smoking by-Laws in Canada 1991. Ottawa: Environmental Health Directorate, Health Protection Branch, 1992. 
10 National Cancer Institute. Major local tobacco control ordinances in the United States. Smoking and Tobacco Control Monograph 3. Bethesda, Maryland, National Institutes of Health, Public Health Service, US Department of Health and Human Services, May 1993. (NIH Publication No. 93-3532.)

11 Jeffery RW, Kelder SH, Forster JL, French SA, Lando HA, Baxter JE. Restrictive smoking policies in the workplace: Effects on smoking prevalence and cigarette consumption. Prev Med 1994; 23 : 78-82.

12 Stave GM, Jackson GW. Effect of a total work-site smoking ban on employee smoking and attitudes. $\mathcal{F}$ Occup Med $1991 ; 33: 884-90$.

13 Wakefield MA, Wilson D, Owen N, Esterman A, Roberts L. Workplace smoking restrictions, occupational status and reduced cigarette consumption. $\mathcal{F}$ Occup Med 1992 34: 693-7.

14 Brigham J, Gross J, Stitzer ML, Felch LJ. Effects of a restricted work-site smoking policy on employees who smoke. Am J Public Health 1994; 84: 773-8.

15 Peterson LR, Helgerson SD, Gibbons CM, Calhoun CR Ciacco KH, Pitchford KC. Employee smoking behavior changes and attitudes following a restrictive policy on worksite smoking in a large company. Public Health Rep 1988; 103: 115-19.

16 Sorensen G, Rigotti N, Rosen A, Pinney J, Prible R. Effects of a worksite nonsmoking policy: Evidence for increased cessation. Am 7 Public Health 1991; 81: 202-4.

17 Sorensen G, Lando H, Pechacek TF. Promoting smoking cessation at the workplace. F Occup Med 1993; 35 1221-6.

18 Scott CJE, Gerberich SG. Analysis of a smoking policy in the workplace. Am Assoc Occup Health Nursing $\mathcal{F} 1989$; 37: 265-73.

19 City of Toronto, Department of the City Clerk. $A$ bylaw respecting smoking in the workplace. Toronto, Ontario, 1988. (No. 23-88.)

20 Pederson LL, Bull SB, Ashley MJ, Garcia JM, Lefcoe NM An evaluation of the workplace smoking by-law in the City of Toronto. Am F Public Health 1993; 83 : 1342-5.

21 City of Etobicoke, Etobicoke Code. Bylaw no. 1988-168, Smoking in workplace areas. Etobicoke, Ontario, 1988.

22 Province of Ontario. Smoking in the Workplace Act, 1989 (Chapter 48, Statutes of Ontario, 1989). Toronto, Queen's Printer for Ontario.

23 City of Toronto. Department of the City Clerk. A bylaw restricting smoking in the workplace. Toronto, 1991. (No. 643-91.)

24 Ying JYC, Abernathy T, Choi BCK. A comprehensive evaluation of the 1993 City of Toronto smoking by-laws. Can f Public Health 1995; 86: 32-6.

25 O'Rourke D, Blair J. Improving random respondent selection in telephone surveys. $\mathcal{F}$ Marketing Res $1983 ; 20$ 428-31.
26 Goodman LA. On simultaneous confidence intervals for multinominal proportions. Technometrics 1965; 7 247-54.

27 Fleiss JL. Statistical methods for rates and proportions. 2nd ed. New York: John Wiley, 1981.

28 Groves RM, Lyberg LE. An overview of nonresponse -1 issues in telephone surveys. In: Groves RM, Biemer PP, O Lyberg LE, Massey JT, Nicholls WL, Waksberg J, eds. Telephone survey methodology. New York: John Wiley,음 1988: 191-211.

29 Prochaska JO, DiClemente CC. Stages of processes of selfchange in smoking: Toward an integrated model of * change. 7 Consult Clin Psychol 1983; 51:390-5.

30 Glasgow RE. Assessment of smoking behavior in relation to $\overrightarrow{\vec{S}}$ work site smoking policies. New York State f Med 1989;ర్ 89: $31-4$.

31 Woodruff TJ, Rosbrook B, Pierce J, Glantz SA. Lower levels of cigarette consumption found in smoke-free $\bar{S}$ workplaces in California. Arch Intern Med 1993; 153: 1485-593.

32 Borland R, Chapman S, Owen N, Hill D. Effects of workplace smoking bans on cigarette consumption. $A m \mathcal{F}^{\mathrm{C}}$ Public Health 1990; 80: 179-80.

33 Fisher KJ, Glasgow RE, Terborg JR. Work site smoking. cessation: A meta-analysis of long-term quit rates from controlled studies. F Occup Med 1990; 32: 429-39.

34 Jeffrey RW, Forster JL, French SA, Kelder SH, Lando 9 HA, McGovern PG, Jacobs DR, Baxter JE. The Health $\vec{\Omega}$ Worker Project: A work-site intervention for weightor control and smoking cessation. Am $\mathcal{f}$ Public Health $1993 ;-$ 83: 395-401.

35 Gomel M, Oldenburg B, Simpson JM, Owen N. Work-site cardiovascular risk reduction: A randomized trial ofo health risk assessment, education, counseling, and in- centives. Am 7 Public Health 1993; 83: 1231-8.

36 Sorensen G, Lando H, Pechacek TF. Promoting smoking 3 cessation at the workplace. Results of a randomized

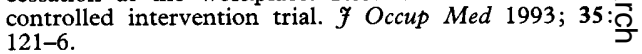

37 Dawley LT, Dawley HH, Glasgow RE, Rice J, Correa P. $\overrightarrow{0}$ Worksite smoking control, discouragement, and cessation. Int 7 Addict 1993; 28: 719-33.

38 Murray RP, Connett JE, Lauger GG, Voekler HT. Error in smoking measures: Effects of intervention on relations of smoking measures : Effects of intervention on relations of cotinine and carbon monoxide to self-re

39 Patrick DL, Cheadle A, Thompson DC, Diehr P, Koepsellō T, Kinne S. The validity of self-reported smoking: A review and meta-analysis. Am F Public Health $1994 ; 84: \frac{\mathrm{D}}{\mathrm{D}}$ 1086-93.

40 Schauffler $\mathrm{HH}$. Integrating smoking control policies into employee benefits: A survey of large California corpora-음 tions. Am $\mathfrak{f}$ Public Health 1993; 83: 1226-30.

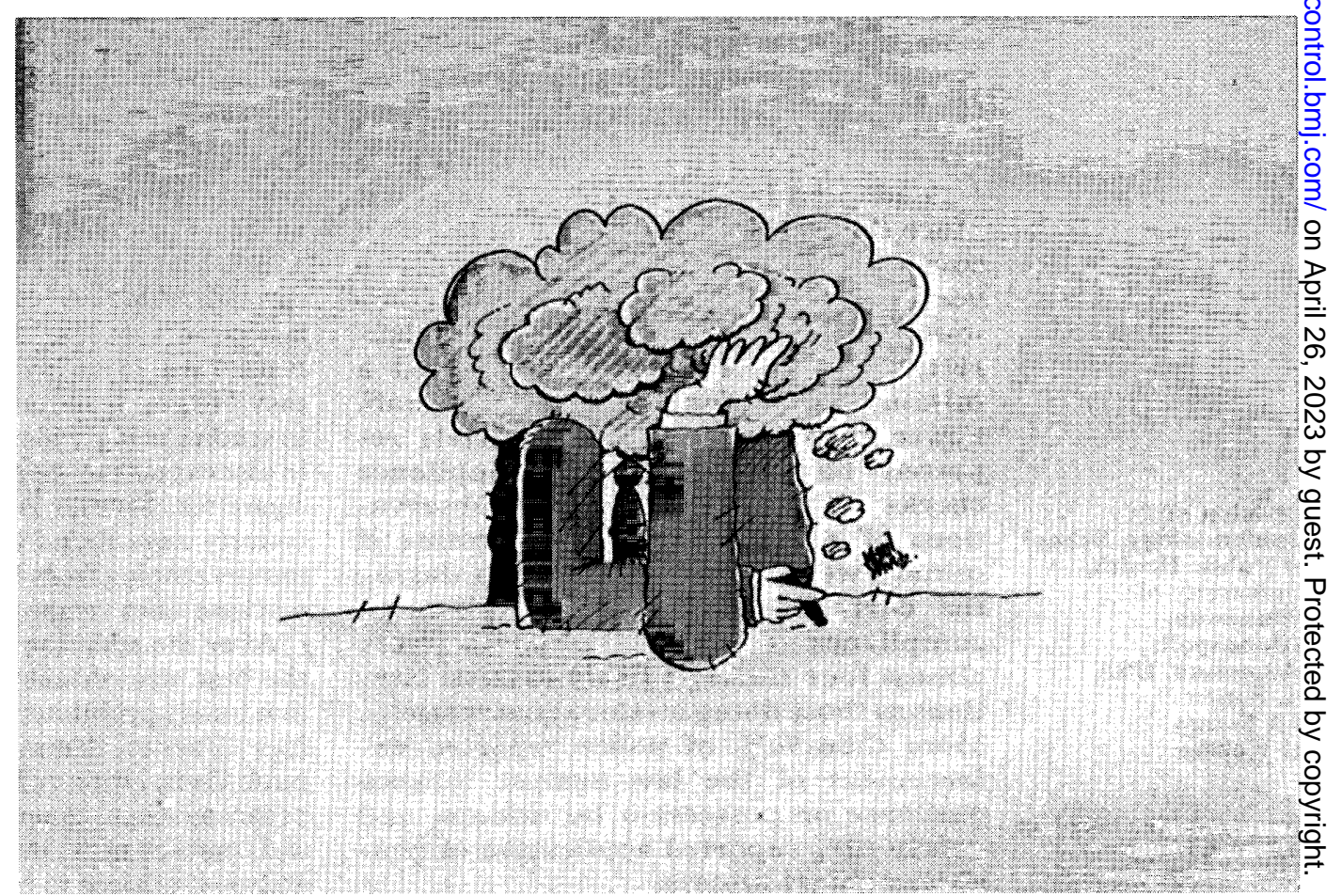

Source: (c) Kâmil Yavuz, Turkey. 